\title{
STRATIGRAPHIC STUDIES AND SURFACE-LAYER FORMATION. A CASE STUDY: EASTERN WILKES LAND, EAST ANTARCTICA \\ (Abstract)
}

by

\author{
I.D. Goodwin
}

(Australian Antarctic Division, Channel Highway, Kingston, Tasmania 7050, Australia)

\begin{abstract}
This paper presents the results of a detailed study on the geomorphic and diagenetic processes of surface-layer formation and its subsequent preservation in the stratigraphic record. The study supplemented stratigraphic studies carried out along a $750 \mathrm{~km}$ ANARE traverse route along the $69^{\circ} \mathrm{S}$ parallel between $112^{\circ}$ and $131^{\circ} \mathrm{E}$ (which approximately follows the $2000 \mathrm{~m}$ contour) in the katabatic wind zone of eastern Wilkes Land.

A 100 cane farm was established at $\mathrm{GD} 03\left(69^{\circ} \mathrm{S}\right.$, $115^{\circ} \mathrm{E} ; 1835 \mathrm{~m}$ a.s.1.), adjacent to a $30 \mathrm{~m}$ deep firn-core drill site. The cane farm was used to monitor seasonal changes in snow accumulation and the type, size, distribution and orientation of the surface micro-relief.

The annual snow accumulation at GD03 is equivalent to $300 \mathrm{~kg} \mathrm{~m}^{-2}$ of water. This annual layer is visibly marked
\end{abstract}

by a multi-layered ice crust, typically $1-2 \mathrm{~mm}$ thick, which is formed in autumn during a hiatus in snow supply. Within the annual layer, single-layered thin ice crusts were observed. These correspond to short hiatus periods, of the order of $2-3$ weeks, during late winter-early spring, and radiation glazes formed during summer.

Density and oxygen-isotope-depth profiles display annual cyclicity within the snow-pack. Considerable horizontal variation was found in a single annual-layer thickness, with respect to ice-crust thickness, snow-density and oxygen-isotope values, and depth-hoar development, when traced in $212 \mathrm{~m}$ cores drilled at $5 \mathrm{~m}$ horizontal spacing.

The observed changes in surface micro-relief distributions over the cane farm have enabled a greater understanding of vertical variations between annual layers observed in the $30 \mathrm{~m}$ firn core. 